\title{
Ability of Aphis gossypii and Myzus persicae to Transmit Cucumber mosaic virus in Single and M ixed Infection with Two Potyviruses to Zucchini Squash*
}

\author{
Zayame Vegette Pinto ${ }^{1}$, J orge A Iberto M arques R ezendeㄹ, Valdir A tsushi Yuki² \& Sônia M aria de Stefano Piedade ${ }^{3}$
}

${ }^{1}$ ESA LQ/USP, Departamento de Entomologia, Fitopatologia e Zoologia A grícola, Piracicaba, SP, 13418-900, ${ }^{2}$ A PTA/Instituto A gronômico de Campinas, Campinas, SP, B razil, ${ }^{3}$ ESA L Q/U SP, Depto. de Ciência Exatas, Piracicaba, SP.

Corresponding author: Jorge A.M. Rezende, E-mail: jamrezen@ esalq.usp.br

Data de chegada: 06/07/2006. A ceito para publicação em: 11/06/2007

1383

\section{RESUMO}

Pinto, Z.V.; Rezende, J .A.M .; Yuki, V.A.; Piedade, S.M .S. E ficiência dos afídeos A phis gossypii e M yzus persicae na transmissão do Cucumber mosaic virus em infecção simples e mista com dois Potyvirus para abobrinha de moita. Summa Phytopathologica, v.34, n.2, p.183-185, 2008

O objetivo desse trabalho foi estudar a eficiência de Aphis gossypii e Myzus persicae na transmissão do vírus do mosaico do pepino (Cucumber mosaic virus, CMV), isoladamente e em mistura com duas espécies de potyvirus (Vírus do mosaico do mamoeiro = Papaya ringspot virus - type W, PRSV-W e Vírus do mosaico amarelo da abobrinha = Zucchini yellow mosaic virus, ZYMV), para planta-testes de abobrinha de moita (Cucurbita pepo). Os dois potyvirus em geral foram transmitidos com mais eficiência pelas duas espécies de afídeos do que o CMV. A transmissão do PRSV-W, ZYMV e CMV separadamente, foi mais eficiente do que em mistura.

Palavras-chave adicionais: Cucurbita pepo; Cucumovirus; transmissão não persitente

\section{ABSTRACT}

Pinto, Z.V.; Rezende, J.A.M.; Y uki, V.A.; Piedade, S.M .S. A bility of Aphis gossypii and M yzus persicae to transmit C ucumber mosaic virus in single and mixed infection with two potyviruses to zucchini squash. Summa Phytopathologica Summa Phytopathologica, v.34, n.2, p.183-185, 2008

The main objective of this work was to investigate the ability of Aphis gossypii and Myzus persicae to transmit Cucumber mosaic virus (CMV) singly and mixed with two potyviruses (Papaya ringspot virus - type W, PRSV-W and Zucchini yellow mosaic virus, ZYMV), to zucchini squash plants (Cucurbita pepo). The results showed that the potyviruses in general were more efficiently transmitted by both species of aphids as compared to CMV. The transmission of PRSV-W, ZYMV and CMV separately was more efficient than in mixture.

Additional keywords: Cucurbita pepo; Cucumovirus; non-persistent transmission

Cucumber mosaic virus (CMV) is a $30-\mathrm{nm}$ icosahedral virus classified in the genus Cucumovirus, family Bromoviridae, which has a tripartite single-stranded, positive sense R N A genome. RN A-1 codes for the la protein, which is also a sub-unit of the CM V replicase complex. RNA-2 codes for the 2 a protein, which is an RNAdependent RNA polymerase and al so integrates the viral replication complex. RNA 3 encodes the 3 a movement protein, which is translated directly from R N 3 , and the coat protein (3b), which is translated from the subgenomic R NA 4. The coat protein contains the determinants for aphid transmission. CM V has a broad host range, including more than 1,200 plant species in over 100 families of dicotyledonous and monocotyledonous angiosperms. It causes mosaic in cucumber and many other cucurbits, fern leaf in tomato, mosaic in banana, and mosaics in many other species of dicotyledonous and monocotyledonous crop, ornamental, fruit and weed plants, including some trees and shrubs (6).

CM V is transmitted by some 80 species of aphids in 33 genera, in a non-persistent non-circulative manner (6), although semi-persistent transmission has also been reported in J apan for some CM V strains and host species combinations (2). Transmission efficiency varies with the strain of the virus, the aphid species, the species of the plant source of virus and test (recipient) plant, the host species used to maintain the aphid colony (6), and the number of CM V transfer to test-plants (5). M yzus persicae (Sulz.) and Aphis gossypii Glov. are the most common species found transmitting CMV, and used for experimental transmission of this virus. M ost strains of $\mathrm{CM} \mathrm{V} \mathrm{can} \mathrm{be}$ transmitted by these two aphids because the specificity of virus transmission is very low. M any species of aphids can transmit multiple strains of CM V (6).

Papaya ringspot virus - type W (PRSV-W) and Zucchini yellow mosaic virus (ZY M V) are species taxonomically classified as bel onging to the genus $P$ otyvirus, in the family P otyviridae. The genome of both consists of a positive-sense, single-stranded RNA molecule that synthesizes a polyprotein that after cleavage gives rise to the capsid protein and to a number of nonstructural proteins with various functions. In nature these potyviruses are transmitted by various 
Table 1. Efficiency of Aphis gossypii and Myzus persicae to transmit Cucumber mosaic virus (CMV) in single or mixed infection with Papaya ringspot virus - type W (PRSV-W), to zucchini squash cV. Caserta.

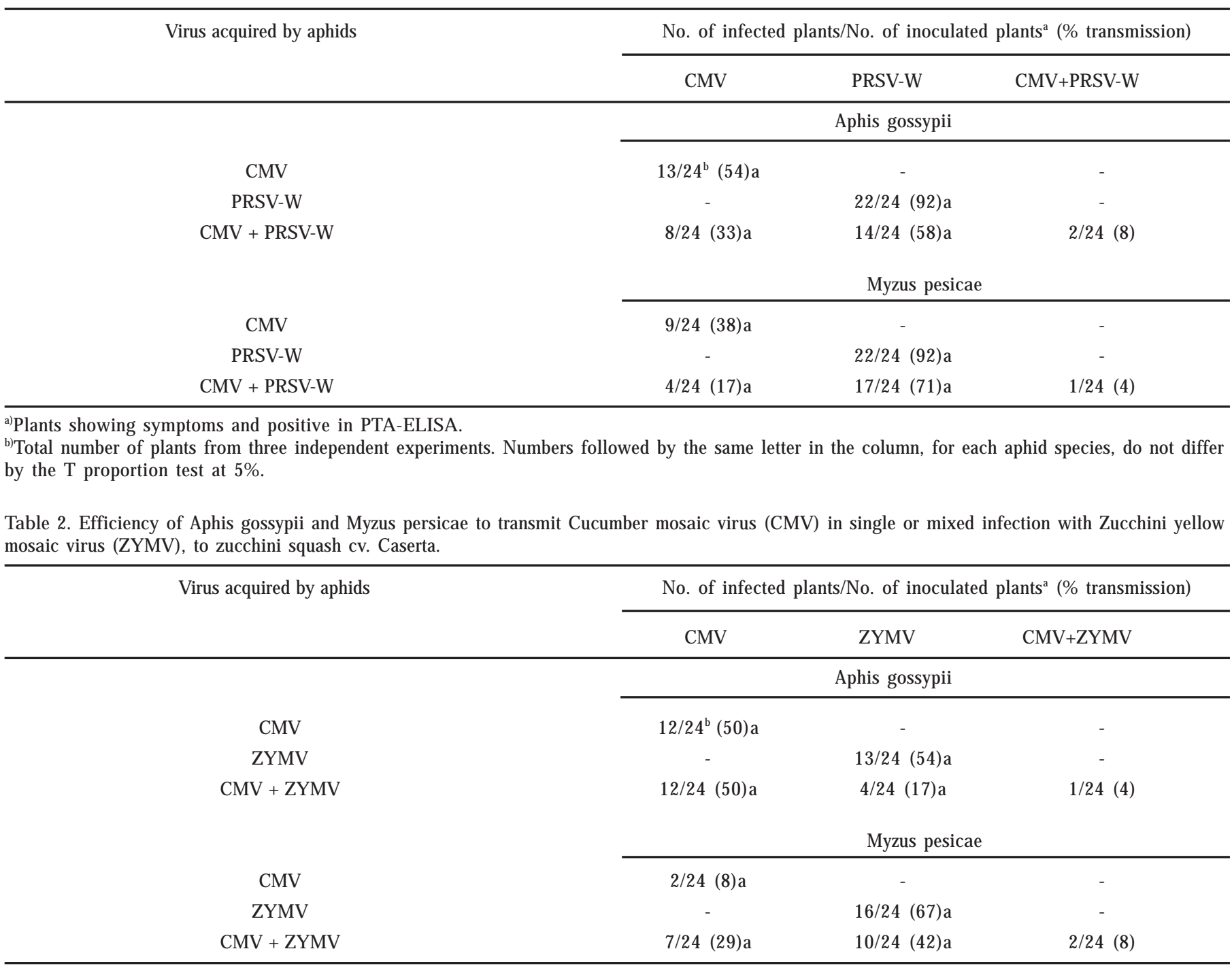

a)Plants showing symptoms and positive in PTA-ELISA.

${ }^{b}$ Total number of plants from three independent experiments. Numbers followed by the same letter in the column, for each aphid species, do not differ by the $T$ proportion test at $5 \%$.

species of aphids, with a non-persistent, non-circulative virus-vector relationship $(1,7)$. The capsid protein as well as the HC-Pro (for hel per component proteinase), which is a nonstructural protein, are involved in aphid transmission according to a bridge model hypothesis (4). These potyviruses are the most important viruses that cause damage in cucurbit crops in B razil and worldwide.

The present study was carried out to investigate the ability of $A$. gossypii and $M$. persicae to transmit B razilian isolates of $C M V$, both separately and mixed with the potyviruses Papaya ringspot virus type W (PRSV-W) or Zucchini yellow mosaic virus (ZY M V), also transmitted in a non-persistent manner to zucchini squash.

Severe isolate of CM V was obtained from field infected cucumber (Cucumis sativus L.), and maintained in zucchini squash plants CV. Caserta. Severe isolates of PRSV-W and ZY M V were collected from field infected zucchini squash and separately maintained in the same species. The identification of the virus isolates was based on ELISA test carried out with polyclonal antisera specific for each virus.

Transmission tests were carried out with test plants of zucchini squash (Cucurbita pepo L. cv. Caserta) grown in $1 \mathrm{~L}$ pots, under greenhouse conditions, at the "Departamento de Entomologia, Fitopatologia e ZoologiaA grícola, ESA LQ", U niversity of São Paulo, Piracicaba, SP.

Virus-free A. gossypii was reared on healthy zucchini squash plantsCv. Caserta, whereas M. persicae on sweet pepper or Raphanus raphanistrum L. plants. A phid transmission was conducted as follows: groups of apterous aphids were starved in plastic boxes for $30 \mathrm{~min}$, and then placed on infected plants for an acquisition access period of $20 \mathrm{~min}$. Groups of 5 aphids were transferred to test plants for an inoculation access period of $1 \mathrm{~h}$. Zucchini squash plants were inoculated at the cotiledonary stage. After inoculation, test plants were sprayed with insecticide to remove the aphids.

The efficiency of A. gossypii and M. persicae to transmit CM V alone and in mixed infection with PRSV-W or ZY M V to zucchini squash plants was evaluated comparing the following five treatments: CM V alone; PRSV-W alone; ZY M V alone; CM V + PRSV-W, and $C M V+Z Y M V$. For mixed transmission, the aphids acquired the 
viruses in double-infected plants. Eight 'C aserta' plants were used for each treatment. Experiments were repeated 3 times for each aphid species.

Virus infections were determined by symptoms appearance and Plate Trapped A ntigen (PTA ) - Enzyme L inked ImmunosorbentA ssay (ELISA), as described by M owat \& Dawson (3), with the following modifications: a) antisera and goat anti-rabbit IgG conjugated to phosphatase alkaline (Sigma-9171) were diluted at 1:1000 and 1:32000, respectively, in Tris- $\mathrm{HCl}, \mathrm{pH} 7.2$, and b) the incubation time at each step was $1.5 \mathrm{~h}$. Polyclonal antisera against CM V, PR SVW and ZY M V were produced in rabbit, at ESA L Q/USP, Piracicaba, SP. Virus positive and healthy negative controls were included in all tests. The substrate $p$-nitrophenil phosphate was diluted at $0.6 \mathrm{mg} /$ $\mathrm{mL}$. PTA-ELISA reactions were recorded 1 hour later by an $\square 960$ ELISA reader ( $M$ etertech, Taiwan) at $A_{405}$. $A$ sample was considered virus-positive if the $A_{405}$ value was greater than three times that of healthy plant extract. Data were compared by pairs (ex: CMV vs CMV + PRSV-W, etc) using the T proportion test at $5 \%$ probability.

Results on the efficiency of A. gossypii and M . persicae to transmit CM V, in single or mixed infection with PRSV-W, to zucchini squash CV. Caserta are presented in Table 1. The average transmission of CM V alone, considering both species of aphids, was approximately $50 \%$ lower than the transmission of PRSV-W, which was $92 \%$. When CM V was acquired together with PRSV-W the transmission of both viruses was reduced, as compared to their single transmission, al though the $T$ proportion test was not significant at $5 \%$. Results of the experiments in which PRSV-W was substituted by ZY M V are presented in Table 2. The efficiency of A. gossypii to transmit CM V and ZY M V alone was al most the same, whereas M. persicae transmitted the potyvirus more efficiently than $C M V$ alone. $W$ hen CM V was acquired together with ZY M V the transmission of the potyvirus was reduced, as compared to its single transmission, but the difference was not significant by the $T$ proportion test at $5 \%$. The absence of significance for the T proportion test is mainly due to the relatively small size of the samples and the variability within each treatment. The transmission rate of $C M V$ was variable. Double infection with CM V + PR SV-W and CM V + ZY M V varied from $4 \%$ to $8 \%$ when transmitted by both species of aphids (Tables 1 and 2 ).

The results of the present work showed that A. gossypii and M . persicae transmitted all three viruses, although the average transmission of PRSV-W was higher $(92 \%)$ than that of ZY M V (54 \% and $67 \%$, respectively). Transmission rates of CM V were the lowest, with A. gossypii being a more efficient vector than $M$. persicae. Higher efficiency of A. gossypii in transmitting seven isolates of CM V was also reported by $\mathrm{Ng} \&$ Perry (5). The data obtained do not permit identify why the potyviruses were, in general, more efficiently transmitted than CM V. A s CM V and the potyviruses (PRSV-W and ZYMV) use different strategies for aphid transmission (4), would be interesting to investigate whether the helper strategy of these potyviruses is more efficient than the coat protein strategy of the CM V

The reduced transmission rate of the cucumovirus and the potyviruses, when acquired simultaneously by both species of aphids, might be due to competition for binding sites on the aphid's stylets, which would reduce the number of available infective particles of each virus for further transmission. The rate of double infection (CM V + PRSV-W and CM V + ZY M V) was very low and the reason(s) for this is unknown. How ever, it is similar to what has been found under field conditions in some cucurbit crops in B razil $(8,9,10)$.

\section{ACK NOW LEDGEMENT}

Thanks to Dr. Hugo K uniyuki, A gência Paulista de Tecnologia dos A gronegócios/Instituto A gronômico de Campinas - APTA/IAC, Campinas, SP, B razil, and D r. Cláudio Lúcio Costa, U niversidade de Brasillia, DF, Brazil, for the critical review of the manuscript.

\section{REFERENCES}

1. Desbiez, C.; Lecoq, H. Zucchini yellow mosaic virus. Plant Pathology, Oxford, v.46, n.6, p.809-829, 1997.

2. Kameya-Iwaki, M.; M urakami, K.; Ito, S.; Hanada, K.; Tanaka, S. Semipersistency of Myzus persicae transmission of cucumoviruses systemically infecting leguminous plants. J ournal of $\mathrm{Gene-}$ ral Plant Pathology, Tokyo, v.66, n.1, p.64-67, 2000.

3. Mowat, W.P.; Dawson, S. Detection of plant viruses by ELISA using crude sap extracts and unfractionated antisera. J ournal of Virological M ethods, A msterdam, v.15, n.3, p.233-247, 1987.

4. Ng, J.C.K.; Falk, B.W. Virus-vector interactions mediating nonpersitent and semipersistent transmission of plant viruses. A nnual Review of Phtopathology, Palo Alto, v.44, p.183-212, 2006.

5. Ng, J.C.K.; Perry, K.L. Stability of the aphid transmission phenotype in cucumber mosaic virus. Plant Pathology, Oxford, v.48, n.3, p.388-394, 1999.

6. Palukaitis, P; Garcia-A renal, F. Cucumber mosaic virus. A A B . Descriptions of Plant Viruses, No. 400, 2003.

7. Purcifull, D.; Edwardson, J.; Hiebert, E.; Gonsalves, D. Papaya ringspot virus. AAB. Description of Plant Viruses, No. 292 1984.

8. Ramos, N.F.; Lima, J.A.A.; Santos, A.A.; Gonçalves, M.F.B. Plantas de meloeiro com infecção mista de espécies de vírus em campos experimentais. Fitopatologia Brasileira, Fortaleza, v.27, supl., p.211, 2002. (Resumo).

9. Stangarlin, O.S.; Dias, P.R.P.; Buriolla, J.E.; Rezende, J.A.M. Incidência de viroses em ensaios de avaliações de genótipos de abóboras e de pepino na região de Dourados/MS. Fitopatologia Brasileira, Fortaleza, v.26, supl., p.532, 2001. (Resumo).

10. Yuki, V.A.; Rezende, J.A.M.; Kitajima, E.W.; B arroso, P.A.V.; Kuniyuki, H.; Groppo, G.A.; Pavan, M.A. Occurrence, distribution and relative incidence of five viruses infecting cucurbits in the State of São Paulo, Brazil. Plant Disease, St. Paul, v.84, n.5, p.516-520, 2000 